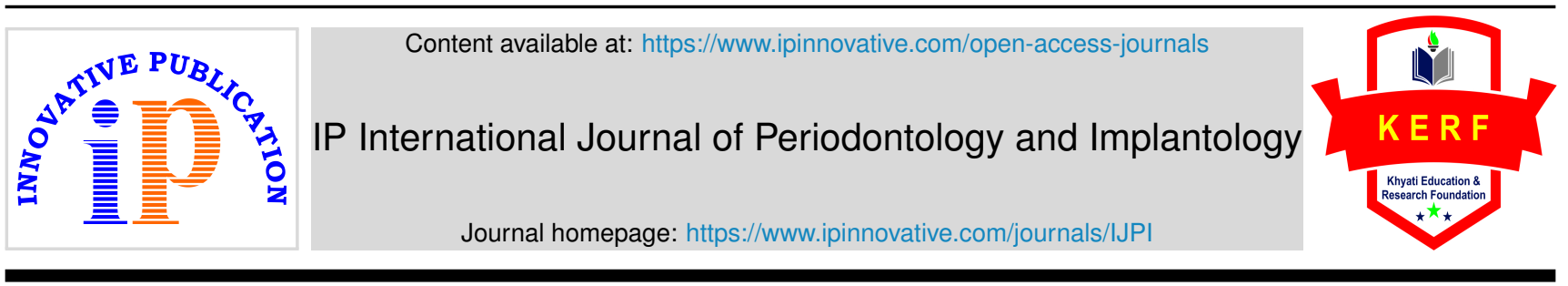

Original Research Article

\title{
Platelet Rich Fibrin (PRF) along with Coronally Repositioned Flap (CRF) compared with that of CRF alone in the management of isolated Miller class-I gingival recession defects: A non-randomized controlled clinical trial
}

\author{
Tony Kurien $\mathbf{J}^{1}$,*, Baiju RM ${ }^{\mathbf{1}}$, Vivek Narayan ${ }^{\mathbf{2}}$ \\ ${ }^{1}$ Dept. of Periodontics, Government Dental College, Kottayam, Kerala, India \\ ${ }^{2}$ Dept. of Public Health Dentistry, Government Dental College, Kottayam, Kerala, India
}

\section{A R T I C L E I N F O}

\section{Article history:}

Received 30-03-2021

Accepted 02-04-2021

Available online 16-04-2021

\section{Keywords:}

Coronally repositioned flap

Gingival recession

Nonrandomized trial

Patient morbidity

Platelet rich fibrin

Root coverage

\begin{abstract}
A B S T R A C T
Background: Periodontal plastic surgical techniques for root coverage are aimed to attain optimal results with less patient discomfort. Platelet-rich fibrin (PRF) containing a wide array of growth factors within fibrin network has shown beneficial results in healing of tissues.

Aims: Study evaluated clinical effects of PRF along with Coronally Repositioned Flap (CRF), test group, and compared it with CRF alone, control group, in the treatment of Miller Class I gingival recession.

Setting and Design: From the subjects who attended the out-patients clinic, a non-randomized controlled clinical study was done on those who satisfied the inclusion criteria.

Materials and Methods: In the control group 29 patients and in the test group 27 patients completed six months of study period. Clinical parameters pertaining to periodontal health and recession anatomy were recorded.

Statistical Analysis: Student t-test was used for intra and inter-group comparison. Multiple linear regression model was developed using three predictor variables.

Results: Mean root cover percentage in PRF and CRF groups were 96.25 \pm 6.89 and $94.59 \pm 10.31$ respectively. PRF group showed reduction in gingival thickness at sixth month. Linear regression model showed a negative association of baseline gingival recession value with complete root coverage.

Conclusion: $\mathrm{CRF}+\mathrm{PRF}$ as well as $\mathrm{CRF}$ alone are equally effective in attaining $>90 \%$ root coverage in Miller Class I gingival recession. The observed clinical benefits along with less invasive procedure involved in PRF technique, shows that it is a promising biomaterial in terms of objective appraisal. However, additional studies overcoming the limitations noticed are needed to ascertain the findings.

(C) This is an open access article distributed under the terms of the Creative Commons Attribution License (https://creativecommons.org/licenses/by/4.0/) which permits unrestricted use, distribution, and reproduction in any medium, provided the original author and source are credited.
\end{abstract}

\section{Introduction}

The focus of periodontal therapy has been evolved from the need of elimination of inflammatory disease process to that of addressing esthetic concerns. Among the various periodontal plastic surgical procedures which have been developed to address the latter issue, root coverage (RC) methods forms the major component as it attains additional patient centered results such as forestalling root caries, curtailment of dentinal sensitivity and improvement of

\footnotetext{
* Corresponding author.

E-mail address: tonyinsurance@yahoo.com (T. Kurien J).
}

plaque control. ${ }^{1}$ Although numerous methods are available for the treatment of gingival recession, and sub-epithelial connective tissue graft (SCTG) method being accepted as the gold standard, this technique may not be fully befitting in regenerating the destroyed attachment apparatus with formation of new cementum and connective tissue fiber linkage. ${ }^{2}$ Hence applications of biomaterials as a substitute for SCTG have been carried out.

Choukroun's platelet-rich fibrin (PRF) is a second generation platelet concentrate containing leukocyte and autologous growth factors embedded in complex fibrin 
matrix. ${ }^{3}$ The fibrin network leads to more efficient cell migration essential for tissue regeneration. The natural polymerization in PRF, due to the non-addition of anticoagulants allows slow release of matrix glycoproteins and growth factors up to 28 days. ${ }^{4}$ For these reasons, PRF usage has shown potential beneficial results in various clinical studies in periodontal therapy and implant procedures. ${ }^{5,6}$

Recently PRF has been used in periodontal plastic surgical procedures, especially in RC treatments to enhance soft tissue wound healing. ${ }^{7}$ The accelerated tissue repair associated with PRF membrane can be attributed to the continuous and gradual release of growth factors. However, based on the meta-analysis, Moraschini and Barboza reported that PRF membrane usage did not enhance the keratinized mucosal width, clinical attachment loss and $\mathrm{RC}$ in comparison with other treatment procedures, ${ }^{8}$ showing inconsistent literature reports. Excellent colour harmonization of treated area with the contiguous soft tissue and non-requirement of a second surgical site are few of the advantages of Coronally Repositioned Flap (CRF) method of RC. ${ }^{9,10}$ Hence the present clinical study was conducted with the aim to assess the effectiveness of PRF along with CRF in the management of isolated Millers Class I buccal gingival recession and to compare with that of CRF alone.

\section{Materials and Methods}

The participants of the study (aged more than 18 years) were from those patients who reported to the department of Periodontics, Government Dental College, Kottayam and selected based on the following inclusion criteria: presence of isolated Miller's Class I gingival recession defects in maxillary or mandibular teeth on buccal surface with a probing depth of $\leq 3 \mathrm{~mm}$ and presence of atleast $0.8 \mathrm{~mm}$ gingival thickness on the gingival recession area, measured according to the method mentioned earlier. ${ }^{11}$ The subjects were excluded if they were smokers and with the presence of high frenum, traumatic occlusion, restoration/caries and cervical abrasions associated with the selected tooth and patients under systemic medications which can affect periodontal health and healing, as well as those patients who were unwilling to give informed consent and reluctant to complete the study period. The study was conducted with the approval of Institutional Ethical Committee (Letter No.IEC/M/04/2012/DCK dated 04/12/2012).

The initial 30 patients were allotted to the test group $(\mathrm{CRF}+\mathrm{PRF})$ and the preceding 30 patients to the control group (CRF). All the patients had undergone initial treatment consisting of ultrasonic debridement and thorough oral hygiene instructions 6 weeks prior to the surgical intervention to attain optimal plaque control and resolve any existing inflammation. On the day of surgery (baseline) and sixth month post-surgery, the following clinical measurements were recorded by a single masked examiner using UNC-15 probe (Hu-Friedy, Chicago, IL), with the help of custom made stent to standardize reference points at mesio-buccal, mid-buccal and disto-buccal aspect of the defect tooth: Gingival Recession (GR)- measured from the cementoenamel junction (CEJ) to the gingival margin, Probing Depth (PD)- the distance from gingival margin to the base of gingival sulcus, Width of Keratinized Gingiva (WKG)- the distance from mucogingival junction (MGJ) to the gingival margin, Clinical Attachment Level (CAL)- measured from a fixed point on the tooth (CEJ) to the base of gingival sulcus, Gingival Thickness (GT)measured according the method mentioned above, and Recession Width (RW)- measured tangentially at the level of CEJ. Recession Area (RA) was scored as the area within the contour of denuded root and Mean Root Coverage Percentage (MRC\%) was calculated from the GR value. Oral hygiene status was quantified based on Full Mouth O'Leary Plaque Score (FMPS). ${ }^{12}$ An FMPS of $<20 \%$ was taken as cut-off to undergo the RC procedure.

Just prior to the initiation of the surgery, PRF preparation was done according to the method described by Choukroun et al (2001). ${ }^{13}$ Briefly, $10 \mathrm{ml}$ of blood was drawn from antecubital vein by venipuncturing and collected in a sterile glass tube without anti-coagulant. It was immediately centrifuged at 2,700 rpm for 12 minutes in a centrifugation machine. From the resultant three basic segments obtained in the tube, the middle layer of fibrin clot (between the topmost acellular plasma and base of red blood cells) was separated using sterile tweezers and scissors. Using sterile compress, a stable fibrin membrane was obtained by squeezing out the fibrin clot.

The surgical protocol of both the study groups consisted of identical design of the overlying flap which was prepared by the following steps. After attaining local anesthesia intra-sulcular incision was started from the line angle of the adjacent mesial tooth, and extended in horizontal direction crossing the interdental papilla towards distal tooth. From the terminal ends of this incision, two oblique vertical incisions were made beyond MGJ (Figure 1a). The resultant mucoperiosteal flap was elevated to expose 2$3 \mathrm{~mm}$ of bone. From the terminal point of bone exposure, the flap elevation proceeded as split-thickness as far as needed to permit advancement of flap to a level coronal to CEJ without tension (Figure 1b). The obtained PRF membrane was placed over the recession, slightly coronal to CEJ in the test group only (Figure 1c). The reflected flap was then repositioned coronally over the PRF membrane passively and stabilized using interrupted sling sutures (non-resorbable 3-0 FilaSilk ${ }^{T M}$, MerilEndo Surgery Pvt. Ltd). Simple loop sutures (non-resorbable) were placed to approximate the vertical incisions (Figure 1d), and periodontal dressing $\left(\mathrm{CoePak}^{\mathrm{TM}} \mathrm{GC}\right.$, IL) was applied over the surgical site.

All the patients were prescribed antibiotics, thrice daily for five days and analgesics, twice daily for three-four 
days and advised to refrain from mechanical plaque control and hard chewing on the treated area. They were also instructed to rinse their mouth using $0.2 \%$ chlorhexidine gluconate (Dr. Reddy's Laboratories India) twice daily for two weeks and then to clean the surgical area with a cotton pellet soaked in chlorhexidine for the next 14 days. Removal of periodontal dressing was done one week after surgery and the sutures by $14^{\text {th }}$ day. Four weeks after the surgery the patients were instructed to resume mechanical plaque control by using a soft tooth brush in a careful roll technique. They were recalled for review examination and needful periodontal care weekly from the day of suture removal for one month and monthly thereafter till the sixth month (Figure 1e). The baseline and sixth month postoperative clinical picture of the control group subject is shown in Figure 2a,b, respectively.

Statistical analysis was carried out with the level of significance (p value) set at 0.05 as the threshold. Student t-test was done to compare the difference in mean values of quantitative variables for intra-group (paired) and intergroup comparisons (unpaired) at baseline and at sixth month. Difference of changes in clinical parameters from baseline to 6 months between the study groups was compared using unpaired t-test. Multiple linear regression models were developed for determining complete root coverage (CRC) using three predictor variables, namely, surgical technique, baseline GR and baseline RA.

\section{Results}

A total of 60 patients (30 each in the study groups) underwent the surgical procedures of the study. However, in the control group only 29 patients and in the test group 27 patients completed the full study period. The mean age of the participants in years was $36.07 \pm 8.86$ and $39.14 \pm 8.7$ in the test and control group respectively. There was no significant difference of subjects' age between the groups. The demographic data of the participants are presented in Table 1.

All the participants showed acceptable standard of plaque control during the study period. Baseline and sixth month post-operative measurements are summarized in Table 2. Except for GT, at the baseline, there were no statistically significant differences in parameters between the study groups. Both the groups showed significant reduction in GR, PD, CAL, RW and RA values at sixth month. Similar significant improvement in WKG and GT scores were observed. A reduction of GT was observed in test group at the end of the study $(\mathrm{p}<0.05)$. Also the PRF group had a higher percentage of RC. However the value was not statistically significant.

Table 3 llustrates the changes in clinical parameter in both the groups at the sixth month follow-up. Comparative analysis showed non-significant changes in GR, PD, CAL, WKG, RW and RA values between the groups. A notable observation is the significant reduction of GT in the test group at the sixth month. The same group had a higher reduction of RW and RA compared to control group ( $>0.05$ ). Table 4 depicts the data pertaining to the linear regression model for predicting complete root coverage. Among the three predictive variables, baseline RA showed a significant negative correlation with the outcome variable (root coverage). $\mathrm{R}$ square value of .400 in the regression analysis showed the high validity of this model. In the test group, $77.8 \%$ of the sites had $90-100 \%$ of root coverage compared to control group (75.9\%), Figure 3.

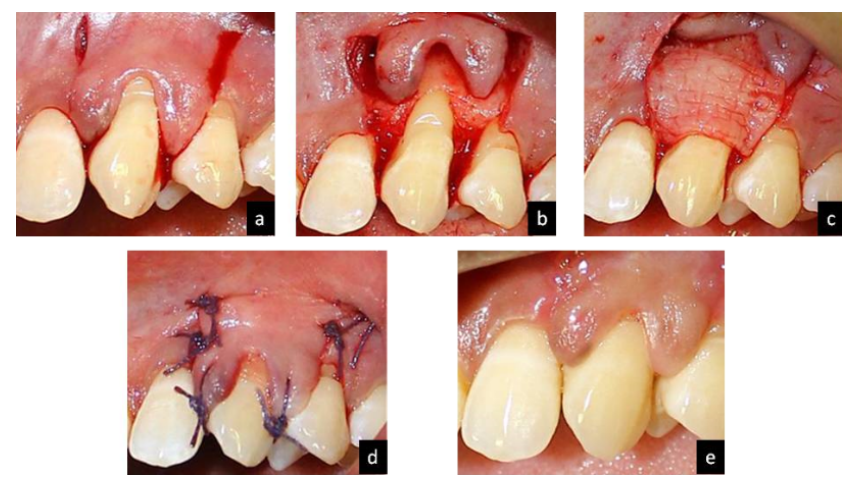

Fig. 1: (a) Incisions placed in relation to 23 region of the test group. (b) Reflection of full-thickness flap to expose 2-3mm bone and split-thickness flap beyond it. (c) Placement of PRF membrane slightly coronal to the CEJ. (d) Coronal displacement of flap and its stabilization using non-resorbable sutures. (e) Post-operative healing after six months.
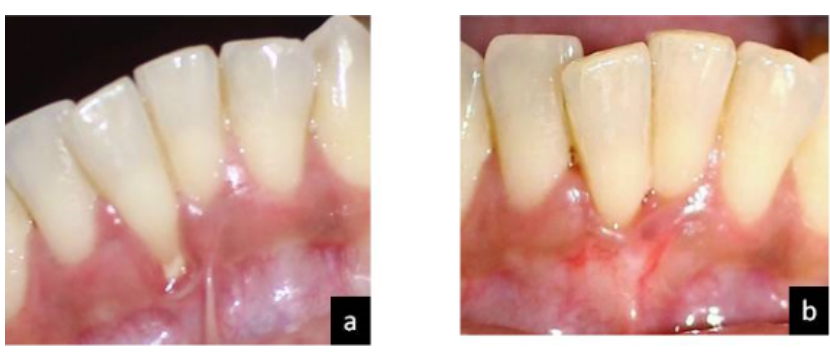

Fig. 2: Controlgroup clinicalpicturesR -(a) Baseline (b) Postoperative healing after six months.

\section{Discussion}

The various periodontal plastic surgical methods which are developed to address gingival recession aims to attain complete root coverage and improve esthetics in a predictable manner with less patient morbidity. The beneficial effects of PRF such as availability of glycanic chain with wide array of cytokines which have synergic effect on healing process have prompted clinicians to use it as a biomaterial to substitute SCTG, to overcome its limitations. ${ }^{7,14}$ However scientific documentations showed 


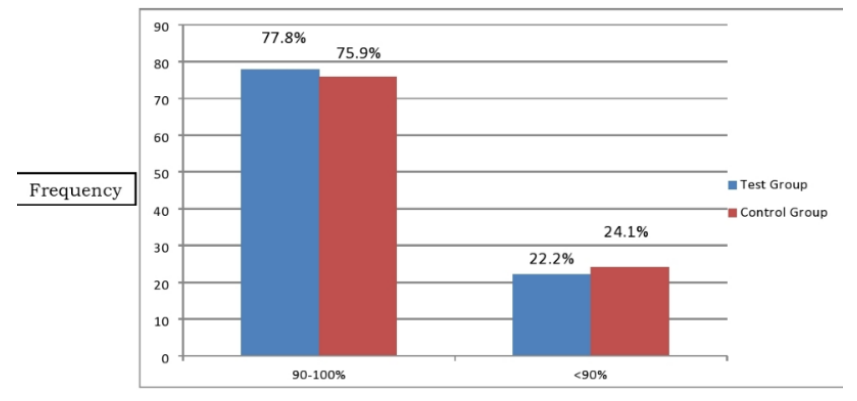

Fig. 3:

Table 1: Demographic data of the study groups.

\begin{tabular}{|c|c|c|c|}
\hline Parameter & $\begin{array}{l}\text { Control } \\
\text { Group }\end{array}$ & $\begin{array}{c}\text { Test } \\
\text { Group }\end{array}$ & S.S \\
\hline $\begin{array}{l}\text { Subjects included in the } \\
\text { study }\end{array}$ & 30 & 30 & \\
\hline $\begin{array}{l}\text { Subjects completed the } \\
\text { study period }\end{array}$ & 29 & 27 & \\
\hline Males & 12 & 10 & \\
\hline Females & 17 & 17 & \\
\hline $\begin{array}{l}\text { Mean age in years } \\
(\text { Mean } \pm \text { S.D) }\end{array}$ & $39.14 \pm 8.7$ & $36.07 \pm 8.86$ & N.S* \\
\hline
\end{tabular}

SD- Standard Deviation; S.S- Statistical Significance; NS- NonSignificant, *- unpaired t-test.

varied clinical outcomes following PRF usage in the treatment of GR. ${ }^{15,16}$ Current literature reports have been conclusive regarding the stability of CRF, as evident by the co-relation between the results after six months and three years and also mentions about the excellent blending between the adjacent tissues and surgical area. ${ }^{17,18}$ Hence the present non-randomized study evaluated the short-term clinical effects of the usage of PRF along with CRF for correcting Miller Class I GR and compared it to that of CRF alone.

The results of the current study demonstrated that both the techniques were effective in reducing GR significantly. Quantitatively, the mean GR at baseline of the test and control group were $2.66 \pm 0.86$ and $2.77 \pm 0.87$ respectively, with all the subjects having Miller Class I GR defects. Studies have shown that the amount of root coverage obtained is associated with the initial recession anatomy. ${ }^{19}$ Hence significant root coverage was achieved in both the groups at sixth month with a slightly higher mean percentage in test group $(96.25 \pm 6.89)$ compared to control group $(94.59 \pm 10.31)$. The co-adjuvant effect of release of growth factors which aids in neoangiogenesis that prevents necrosis, along with adhesive mechanical property attributable to the fibrin in PRF maintains the flap in a higher stable position and allows better root coverage. ${ }^{20}$

Treatments in both the groups resulted in significant gain in CAL and in the test group there was slightly higher PD reduction. This can be explained by the observation from
Table 2: Descriptive statistics of the clinical parameters measured at baseline and 6 months.

\begin{tabular}{|c|c|c|c|}
\hline Parameter & $\begin{array}{c}\text { Baseline } \\
(\text { Mean } \pm \text { S.D })\end{array}$ & $\begin{array}{c}6^{t h} \text { month } \\
(\text { Mean } \pm \text { S.D })\end{array}$ & $\begin{array}{c}\text { Baseline v/s } \\
6^{\text {th }} \text { month } \\
\text { S.S }\end{array}$ \\
\hline FMPS & & & \\
\hline Test Group & $17.81 \pm 5.42$ & $15.52 \pm 4.61$ & $\mathrm{~S}^{*}$ \\
\hline $\begin{array}{l}\text { Control } \\
\text { Group }\end{array}$ & $19.28 \pm 5.35$ & $16.21 \pm 3.6$ & $\mathrm{~S}^{*}$ \\
\hline $\begin{array}{l}\mathrm{p} \text {-value } \\
\text { GR }\end{array}$ & N.S\# & N.S\# & \\
\hline Test Group & $2.66 \pm 0.86$ & $0.16 \pm 0.31$ & $\mathrm{~S}^{*}$ \\
\hline $\begin{array}{l}\text { Control } \\
\text { Group }\end{array}$ & $2.77 \pm 0.87$ & $0.24 \pm 0.43$ & $\mathrm{~S}^{*}$ \\
\hline $\begin{array}{l}\text { p-value } \\
\text { PD }\end{array}$ & N.S\# & N.S\# & \\
\hline Test Group & $1.75 \pm 0.75$ & $0.24 \pm 0.42$ & $\mathrm{~S}^{*}$ \\
\hline $\begin{array}{l}\text { Control } \\
\text { Group }\end{array}$ & $1.86 \pm 0.71$ & $0.19 \pm 0.36$ & $\mathrm{~S}^{*}$ \\
\hline $\begin{array}{l}\text { p-value } \\
\text { CAL }\end{array}$ & N.S\# & N.S\# & \\
\hline Test Group & $4.42 \pm 1.22$ & $0.40 \pm 0.36$ & $\mathrm{~S}^{*}$ \\
\hline $\begin{array}{l}\text { Control } \\
\text { Group }\end{array}$ & $4.67 \pm 1.26$ & $0.43 \pm 0.59$ & $\mathrm{~S}^{*}$ \\
\hline $\begin{array}{l}\text { p-value } \\
\text { WKG }\end{array}$ & N.S\# & N.S\# & \\
\hline Test Group & $2.22 \pm 0.48$ & $4.01 \pm 0.71$ & $\mathrm{~S}^{*}$ \\
\hline $\begin{array}{l}\text { Control } \\
\text { Group }\end{array}$ & $2.2 \pm 0.39$ & $4.19 \pm 0.81$ & $\mathrm{~S}^{*}$ \\
\hline $\begin{array}{l}\text { p-value } \\
\text { GT }\end{array}$ & N.S\# & N.S\# & \\
\hline Test Group & $1.18 \pm 0.27$ & $0.96 \pm 0.11$ & $\mathrm{~S}^{*}$ \\
\hline $\begin{array}{l}\text { Control } \\
\text { Group }\end{array}$ & $0.95 \pm 0.10$ & $1.11 \pm 0.33$ & $\mathrm{~S}^{*}$ \\
\hline $\begin{array}{l}\text { p-value } \\
\text { RW }\end{array}$ & S\# & S\# & \\
\hline Test Group & $2.86 \pm 0.37$ & $0.57 \pm 1.0$ & $\mathrm{~S}^{*}$ \\
\hline $\begin{array}{l}\text { Control } \\
\text { Group }\end{array}$ & $2.71 \pm 0.43$ & $0.58 \pm 1.08$ & $\mathrm{~S}^{*}$ \\
\hline $\begin{array}{l}\text { p-value } \\
\text { RA }\end{array}$ & N.S\# & N.S\# & \\
\hline Test Group & $7.54 \pm 2.43$ & $0.36 \pm 0.65$ & $\mathrm{~S}^{*}$ \\
\hline $\begin{array}{l}\text { Control } \\
\text { Group }\end{array}$ & $7.46 \pm 2.45$ & $0.52 \pm 1 . \mathrm{OO}$ & $\mathrm{S}^{*}$ \\
\hline $\begin{array}{l}\text { p-value } \\
\text { Percentage } \\
\text { of root } \\
\text { coverage }\end{array}$ & N.S\# & N.S\# & \\
\hline Test Group & & $96.25 \pm 6.89$ & \\
\hline $\begin{array}{l}\text { Control } \\
\text { Group }\end{array}$ & & $\begin{array}{c}94.59 \\
\pm 10.31\end{array}$ & N.S* \\
\hline
\end{tabular}

FMPS-Full Mouth Plaque Score, GR-Gingival Recession, PD-Periodontal Pocket, CAL-Clinical Attachment Loss, WKG- Width of Keratinized Gingiva, GT- Gingival Thickness, RW-Recession Width, RA- Recession Area, SD- Standard Deviation; S.S- Statistical Significance; NS- NonSignificant, S-Significant at $\mathrm{p}<0.05,{ }^{*}$-paired t-test, \#-unpaired t-test. 
Table 3: Mean change in clinical parameters over 6 months period between the treatment groups.

\begin{tabular}{lccc}
\hline Parameter & $\begin{array}{c}\text { Test Group } \\
(\mathbf{M e a n} \pm \text { S.D) } \\
\text { GR }\end{array}$ & $\begin{array}{c}\text { Control Group } \\
(\mathbf{M e a n} \pm \text { S.D) }\end{array}$ & S.S \\
$\begin{array}{l}\text { Reduction } \\
\text { PD }\end{array}$ & $1.51 \pm 0.69$ & $1.67 \pm 0.68$ & N.S* \\
$\begin{array}{l}\text { Reduction } \\
\text { CAL }\end{array}$ & $4.01 \pm 0.86$ & $4.24 \pm 1.01$ & N.S* \\
$\begin{array}{l}\text { Reduction } \\
\text { WKG }\end{array}$ & $1.79 \pm 0.50$ & $1.98 \pm 0.93$ & N.S* \\
$\begin{array}{l}\text { Increase } \\
\text { GT Change }\end{array}$ & $-0.21 \pm 0.28$ & $0.16 \pm 0.37$ & S* \\
$\begin{array}{l}\text { RW } \\
\text { Reduction }\end{array}$ & $2.28 \pm 1.16$ & $2.18 \pm 1.19$ & N.S* \\
RA & $7.18 \pm 2.14$ & $6.94 \pm 2.07$ & N.S* \\
Reduction & & & \\
\hline
\end{tabular}

GR-Gingival Recession, PD-Periodontal Pocket, CAL-Clinical Attachment Loss, WKG- Width of Keratinized Gingiva, GT- Gingival Thickness, RW-Recession Width, RA- Recession Area , SD-Standard Deviation; S.S- Statistical Significance, NS- Non-Significant, S-Significant at $\mathrm{p}<0.05, *$ - unpaired t-test.

Table 4: Linear multiple regression model for predicting complete root coverage.

\begin{tabular}{lcc}
\hline Predictor Variables & $\begin{array}{c}\text { Unstandardized } \\
\text { Coefficients }\end{array}$ & S.S \\
Surgical Technique & .490 & N.S \\
GR ( Baseline) & -.9772 & S \\
RA ( Baseline) & 1.344 & N.S \\
\hline
\end{tabular}

$\mathrm{R}$ Square $=.400$, ANOVA p value $<001$, GR-Gingival Recession, RARecession Area; S S- Statistical Significance, NS- Non-Significant

the biopsy studies which showed good blending of epithelial layer to the tissues of recipient site as well as deeper retepegs in $\mathrm{CRF}+\mathrm{PRF}$ group providing resistance to external irritants. ${ }^{21,22}$ But Eren and Atilla $(2014)^{23}$ reported absence of change in PD in PRF treated group and suggested that the tissue consistency might have remained unchanged. The observation of augmentation of WKG is in agreement with earlier reports. ${ }^{24,25}$ It is known that the genetic information from the connective tissue will determine the character of surface epithelium. The biologic characteristics of PRF with the growth factors influencing tissue proliferation may to certain extent explain the above observations. However this supposition needs to be ascertained in future biologic studies. In a recent meta-analysis the authors observed from the comparison between PRF and SCTG that, the only clinical variable that differed significantly was the WKG. ${ }^{26}$

Eventhough both the groups showed a salient change of clinical parameters from baseline to six months, intergroup analysis were not significant. Similar observations were made earlier. ${ }^{27}$ They however, reported a significant increase in GT in the CRP+PRF group. In our study also, a significant difference between the groups was observed in GT scores with the test group showing reduction in
GT. There was a significant difference in baseline values of GT between the groups. This difference would have probably influenced the above finding post-operatively also. However, this reduction of GT did not inflict the final recession measurements as evident by the higher mean RA reduction in the PRF group. This concurs with the earlier report that the different thresholds of GT did not consort with any significant difference in root coverage within treatment groups (CRF either in conjunction with PRF membrane or without). ${ }^{15}$

In an attempt to predict the CRC by a linear regression model, the baseline GR score showed an inverse association. This is in agreement with the report by Chambrone and Tatakis (2015). ${ }^{28}$ Shallow GR, classified as Miller Class I and II may have mean complete root coverage of $46.6 \%$ and reduced further as the GR depth increased. In other words, as the size of the recession defect increases, less root coverage should be expected. ${ }^{29}$ From a clinical point of view, since the baseline RW and RA values of the test group were higher than the control group, a significant difference could not be attained at sixth month post-surgically.

Based on systematic review and meta-analysis of guided tissue regeneration based RC procedures, the reported limitations are; membrane exposure and foreign body reactions associated with bioresorbable membranes. ${ }^{30,31}$ Inherent drawbacks of SCTG consists of the need for a second surgical site and associated patient discomfort, limited amount of graft available and technical skill requirements. PRF membrane technique overcomes all of the above mentioned impediments. This study employed a Leukocyte-rich PRF (L-PRF), the benefits of which are the generation of strong fibrin architecture, anti-infective activity, increased leukocyte degranulation and slow release of growth factors. ${ }^{32,33}$ Also, since the examiner was blinded regarding the group in which the subject was involved, any bias pertaining to the clinical measurements were eliminated. However few limitations to mention with regard to the present clinical study are; the non-randomized study design, the short period of follow-up measurements, less number of GR sites which were treated and the inclusion of only Miller Class I GR defects.

The present controlled clinical trial has shown that CRF alone or in combination with PRF are effective methods to manage Miller Class I gingival recession defect. Although there was a reduction of gingival thickness, successful results seen at sixth month post-surgically with a higher percentage of root coverage in the test group highlights the clinical advantage of PRF membrane. PRF appears to be a promising autologous biomaterial for root coverage, which involves a less invasive technique and wane patient morbidity. It needs to be emphasized that studies comprising of more number of subjects, with long term patient-centered and clinical outcome evaluation needs to be conducted in order to substantiate the documented results with PRF 
usage.

\section{Conflicts of Interest}

All contributing authors declare no conflicts of interest.

\section{Source of Funding}

None.

\section{References}

1. McGuire M, Cochran DL. Evaluation of Human Recession Defects Treated with Coronally Advanced Flaps and Either Enamel Matrix Derivative or Connective Tissue. Part 2: Histological Evaluation. J Periodontol . 2003;74(8):1126-35. do1:10.1902/jop.2003.74.8.1126.

2. Trombelli L. Periodontal regeneration in gingival recession defects. Periodontol. 2000;19(1):138-50.

3. Ehrenfest DMD, Corso MD, Diss A, Mouhyi J, Jean-Baptiste C. Three-Dimensional Architecture and Cell Composition of a Choukroun's Platelet-Rich Fibrin Clot and Membrane. J Periodontol . 2010;81(4):546-55. do1:10.1902/jop.2009.090531.

4. He L, Lin Y, Hu X, Zhang Y, Wu H. A comparative study of plateletrich fibrin (PRF) and platelet-rich plasma (PRP) on the effect of proliferation and differentiation of rat osteoblasts in vitro. Oral Surg Oral Med Oral Pathol Oral Radiol Endod. 2009;108(5):707-13.

5. Sharma A, Pradeep AR. Treatment of 3-wall Intrabony defects in patients with chronic periodontitis with autologous plateletrich fibrin:A randomized controlled clinical trial. J Periodontol. 2011;82(12):1705-12.

6. Diss A, Dohan DM, Mouhyi J, Mahler P. Osteotome sinus floor elevation using Choukroun's platelet-rich fibrin as grafting material: a 1-year prospective pilot study with microthreaded implants. Oral Surg, Oral Med, Oral Pathol, Oral Radiol Endodontol. 2008;105(5):572-9. do1:10.1016/j.tripleo.2007.08.021.

7. Eren G, Atilla G. Platelet-Rich Fibrin in the Treatment of Bilateral Gingival Recessions. Clin Adv Periodontics . 2012;2(3):154-60. do1:10.1902/cap.2012.110074

8. Moraschini V, Barboza ESP. Use of Platelet-Rich Fibrin Membrane in the Treatment of Gingival Recession: A Systematic Review and Meta-Analysis. J Periodontol . 2016;87(3):281-90. do1:10.1902/jop.2015.150420.

9. de Sanctis M, Zucchelli G. Coronally advanced flap: a modified surgical approach for isolated recession-type defects: Three-year results. J Clin Periodontol . 2007;34(3):262-8. [01:10.1111/.1600$05 \times 20060030$.

10. Cairo F, Pagliaro U, Nieri M. Treatment of gingival recession with coronally advanced flap procedures: a systematic review. J Clin Periodontol . 2008;35(8):136-62. doi:10.1111/.1600$051 \times 200801267 x$.

11. Vandana KL, Savitha B. Thickness of gingiva in association with age, gender and dental arch location. J Clin Periodontol . 2005;32(7):82830. do1:10.1111/.1600-051x.2005.00757.X.

12. O'Leary TJ, Drake RB, Naylor JE. The Plaque Control Record. $J$ Periodontol . 1972;43(1):38. doi:10.1902/10p.1972.43.1.38

13. Choukroun J, Adda F, Schoeffler C, Vervelle A. An opportunity in perio-implantology: The PRF ( in French). Implantodontie. 2001;42:55-62.

14. Dohan DM, Choukroun J, Diss A, Dohan SL, Dohan AJ, Mouhyi $\mathrm{J}$, et al. Platelet-rich fibrin (PRF): a second-generation platelet concentrate. Part II: platelet-related biologic features. Oral Surg Oral Med Oral Pathol Oral Radiol Endod. 2006;101(3):45-50.

15. Aroca S, Keglevich T, Barbieri B, Gera I, Etienne D. Clinical Evaluation of a Modified Coronally Advanced Flap Alone or in Combination With a Platelet-Rich Fibrin Membrane for the Treatment of Adjacent Multiple Gingival Recessions: A 6-Month Study. J Periodontol. 2009;80(2):244-52. do1:10.1902/Jop.2009.080253
16. Jankovic S, Aleksic Z, Milinkovic I, Dimitrijevic B. The coronally advanced flap in combination with platelet-rich fibrin (PRF) and enamel matrix derivative in the treatment of gingival recession: a comparative study. Eur J Esthet Dent. 2010;5(3):260-73.

17. Jepsen K, Stefanini M, Sanz M, Zucchelli G, Jepsen S. Long-Term Stability of Root Coverage by Coronally Advanced Flap Procedures. J Periodontol. 2017;88(7):626-33. do1:10.1902/jop.2017.160767.

18. Stefanini M, Marzadori M, Aroca S, Felice P, Sangiorgi M, Zucchelli $\mathrm{G}$, et al. Decision making in root-coverage procedures for the esthetic outcome. Periodontol. 2000;77(1):54-64.

19. Chambrone L, Ortega MAS, Sukekava F, Rotundo R, Kalemaj Z, Buti $\mathrm{J}$, et al. Root coverage procedures for treating single and multiple recession-type defects: An updated Cochrane systematic review. $J$ Periodontol. 2019;90(12):1399-422. do1:10.1002/jper.19-0079.

20. Corso MD, Sammartino G, Ehrenfest DMD. Letter to the Editor: Re: "Clinical Evaluation of a Modified Coronally Advanced Flap Alone or in Combination With a Platelet-Rich Fibrin Membrane for the Treatment of Adjacent Multiple Gingival Recessions: A 6-Month Study". J Periodontol. 2009;80(11):1694-7. do1:10.1902/jop.2009.090253.

21. Eren G, Kantarc1 A, Sculean A, Atilla G. Vascularization after treatment of gingival recession defects with platelet-rich fibrin or connective tissue graft. Clin Oral Investig. 2016;20(8):2045-53. doi:-10.1007/s00784-(25-1697-8

22. Guiha R, Khodeiry SE, Mota L, Caffesse R. Histological Evaluation of Healing and Revascularization of the Subepithelial Connective Tissue Graft. J Periodontol. 2001;72(4):470-8. do1:10.1902/jop.2001.72.4.470.

23. Eren G, Atilla G. Platelet-rich fibrin in the treatment of localized gingival recessions: a split-mouth randomized clinical trial. Clin Oral Investig. 2014;18(8):1941-8. 10i:10.1007/s00784-013- [70-51.

24. Jankovic S, Aleksic Z, Klokkevold P, Lekovic V, Dimitrijevic B, Kenney EB, et al. Use of platelet-rich fibrin membrane following treatment of gingival recession: a randomized clinical trial. Int $J$ Periodontics Restor Dent. 2012;32(2):41-50.

25. Turer OU, Ozcan M, Alkaya B, Surmeli S, Seydaoglu G, Haytac $\mathrm{MC}$, et al. Clinical evaluation of injectable platelet-rich fibrin with connective tissue graft for the treatment of deep gingival recession defects: A controlled randomized clinical trial. J Clin Periodontol . 2020;47(1):72-80. do1:10.1111/jcpe.13193.

26. Rodas MR, de Paula B, Pazmiño VFC, Vieira FL, Junior JFS, Silveira EMV, et al. Platelet-Rich Fibrin in Coverage of Gingival Recession: A Systematic Review and Meta-Analysis. Eur J Dent. 2020;14(2):31526. dol:-1055/s-()040-1701907.

27. Thamaraiselvan M, Elavarasu S, Thangakumaran S, Gadagi JS, Arthie T. Comparative clinical evaluation of coronally advanced flap with or without platelet rich fibrin membrane in the treatment of isolated gingival recession. J Indian Soc Periodontol. 2015;19(1):66-71.

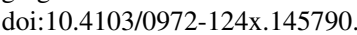

28. Chambrone L, Tatakis DN. Periodontal Soft Tissue Root Coverage Procedures: A Systematic Review From the AAP Regeneration Workshop. J Periodontol. 2015;86(2 Suppl.):S8-S51. do1:10.1902/jop.2015.130674.

29. Shieh A, Wang H, O’Neal R, Glickman GN, MacNeil RL. Development and Clinical Evaluation of a Root Coverage Procedure Using a Collagen Barrier Membrane. J Periodontol. 1997;68(8):770_ 8. do1:10.1902/jop.1997.68.8.770.

30. Danesh-Meyer MJ, Wikesjö UM. Gingival recession defects and guided tissue regeneration: a review. J Periodontal Res. 2001;36(6):341-54. do1:10.1034/].1600-0765.2001.360601.x.

31. Al-Hamdan K, Eber R, Sarment D, Kowalski C, Wang H. Guided Tissue Regeneration-Based Root Coverage: Meta-Analysis. $\quad J$ Periodontol . 2003;74(10):1520-33. do1:10.1902/jop.2003.14.10.1520.

32. Sharma A, Pradeep AR. Autologous platelet-rich fibrin in the treatment of mandibular degree II furcation defects: A randomized clinical trial. J Periodontol. 2011;82(10):1396-403.

33. Castro AB, Meschi N, Temmerman A, Pinto N, Lambrechts P, Teughels W, et al. Regenerative potential of leucocyte- and platelet-rich fibrin. Part A: intra-bony defects, furcation defects and 
periodontal plastic surgery. A systematic review and meta-analysis. $J$ Clin Periodontol . 2017;44(1):67-82. doi:10.1111/jcpe.12643.

\section{Author biography}

Tony Kurien J, Assistant Professor

Baiju RM, Additional Professor
Vivek Narayan, Assistant Professor

Cite this article: Kurien J T, Baiju RM, Narayan V. Platelet Rich Fibrin (PRF) along with Coronally Repositioned Flap (CRF) compared with that of CRF alone in the management of isolated Miller class-I gingival recession defects: A non-randomized controlled clinical trial. IP Int $J$ Periodontol Implantol 2021;6(1):42-48. 